\title{
The finish line
}

\author{
My apologies to chance for calling it \\ necessity. \\ My apologies to necessity, if I'm \\ mistaken, after all. \\ Please don't be angry, happiness, \\ That I take you as my due. \\ May my dead be patient \\ with the way my memories fade \\ My apologies to time, \\ For all the world I overlook each \\ second. (Wislawa Szymborska, Under \\ One Small Star).
}

This ward is set up in such a way as to have eight patients in each section, immediately in front of the nurse's station, behind which I am standing. I prepare the blood results before the consultant comes and asks me whether I have any answers to his questions, and if not why not, since they are the same questions that he asked me yesterday.

I have my share of the work, and my colleague (another SHO) has her's. I am pleased that there has been a just division of labour, and in any case her presence is always reassuring since she is more experienced than I, and so can help me out of the occasional awkward moment.

$\mathrm{He}$ arrives, and I observe he is in a good mood, and the ward round begins.

I, the most junior, push the notes trolley around, and thankfully she does most of the talking. She is preparing for MRCP, and so he asks her all sorts of questions to which she gives all sorts of answers. I, on the other hand, remain silent, and scribble down the various jobs that he has asked of us: 'Chase Mrs B's bloods', 'Mr X needs CXR', and so on.

We finally get to $\mathrm{Mr} \mathrm{L}$, whose bloods are also back, and the $\mathrm{SHO}$ forewarns the consultant. We were partially expecting this. He had some weird haematological thing, and the consultant haematologist had spoken with my colleague earlier and confirmed that it was the bad news they were expecting. Prognosis: 'about 9 months'.

'Your blood results are back' ... 'and I'm afraid it's not good news'. My mind flashes back to med school, and sessions on 'how to break bad news'. The consultant is doing well. The inevitable follows:

'How long, Doc?'

'About 9 months'.

We wait for a minute or two in an uncomfortable silence made only slightly more comfortable by the experience of the consultant who's obviously been in these uncomfortable silences before. And in this moment I see in Mr L's eyes a look. He knows he is dying. He has been on this earth for 58 years, and has not been dying, but now there's no denying it.

'Well', I think ... as I try (with success) to quickly forget this and get on with the rest of the ward round, 'Thank God I'm not dying ...'

Reflective meditation begins where mindless distraction ends. With lights dimmed and external noise reduced to a minimum, one can observe the ceaseless flow of a mind that never seems to tire of being active.

As an object of such meditation, the certainty of death is supremely successful in challenging our most deep seated assumptions about living permanent lives in a permanent world, to which assertions pertaining to the possibility of our 'notbeing' are as distant from our consciousness as are Mr L's blood results when I am watching this week's episode of 'Only Fools and Horses'.

The absurdity of be-ing at all, and the questions this raises, are so expertly concealed beneath layers of (often senseless) distraction, that they are, rather sadly, never addressed, since they are never recognised. So Mr L's death is seen as an unfortunate and sad event rather than what it really is: a tragically beautiful but inevitable conclusion that lies at the heart of all phenomena.

In distraction, I find comfort and security in the illusion of permanence which, rather bizarrely, I have been responsible for concocting from the outset. Yet sadly, it is this distraction which distances me to ever greater lengths from $M r L$ in particular, and the rest of my patients in general. 'Their problems' become too distant from me for me to entertain them, while I busy myself indulging in favourite pastimes, as I listen for the sixteenth time to 'The finish line' by Snow Patrol.

What if I were instead to listen to my beating heart, and feel its life-sustaining actions? What if I were to focus on the miracle that is my breathing, and ask 'what is this?' Can I see that death doesn't only happen to others, and not only to those unnoticed old souls, ravaged by dementia, and forgetfulness; or those povertystricken Africans placed conveniently out of both sight and mind? Can I see that I am not 'going to die', but that I am, in each and every moment, engaged in the process of dying? How does this affect my relationship with $\mathrm{Mr} \mathrm{L}$ ?

Calm and focused awareness observes this body, its positions, the feelings, the moods which arise and fade within it's mental elements. It observes its responses, its habits. It accepts that it was born, and humbly finds itself in the same existential boat in which are all other beings, a boat which is heading towards only one destination; it notices its attachments to the world, to physical pleasures, relationships, family, friends, work.

Reflection on the certainty of death gives human interaction a refreshing air of authenticity which breaks through habitual interactions based on the confused mess of 'wanting/ not wanting', and generates relationships based on the only truth amidst the mass of untruths.

So I can sit with $M r L$ and ask him about his childhood, and about how he met his wife, and who made the first move, when they first met. I can recognise this being as a dying individual, no different from the one to whom he is speaking. I can listen to his fears, and I can be open to his tears, and his concerns. I can laugh with him, as he recalls his 'good times'. I can recognise his impermanence, as he will, and I can recognise my impermanence. I can recognise our impermanence. 
And when the time comes for $\mathrm{Mr} L$ to breathe his last, I can remember him fondly, and remember all that I have learned from our brief interaction.

And I will continue to push this trolley, and collect blood results hurriedly lest the consultant should get annoyed. I will continue to avoid being asked complicated medical questions by him, especially when he is in a bad mood. And with the arrival of the next abnormal blood results, and the breaking of bad news that will follow, I will remember that my role is not to offer sympathy for the suffering of a patient filled with fear, or try to fill awkward silences, but to participate in the relieving of a suffering which is ours, as together, and relentlessly, we move towards the finish line.

\section{Majid Rehman Khan}

DOI: 10.3399/bjgp09X472764

\section{Occupational health specialists in primary care: up-to-date with changing times?}

Primary care practitioners need to be unified, collaborating to continually improve access to care for all our patients, while maintaining our own traditions of expertise.

The Health, Work and Wellbeing agenda $^{1}$ set by Dame Carol Black in 2005 aims to guide the jobless into sustained employment while also maintaining the health of those currently in employment. How can we provide the occupational health expertise required to support and develop this agenda, locally? I propose the idea of occupational health practitioners joining forces with other specialist services within the fledging GPled health centres. ${ }^{2}$ By providing services centrally they could then become a resource for all GPs within the primary care trust area.

These versatile occupational health practitioners offer a broad knowledge base of employee welfare, occupations, and health and safety law. We already support many patients as employees returning to the working environment, whether their conditions were acute or causing them chronic ill health. We are used to negotiating with employers, unions, human resources, and safety personnel, for patients' planned and safe return to work.

With the inclusion of occupational health practitioners in GP-led health centres, there could be numerous advantages that would certainly add value to the phrase 'collaborative working'. One could push the boundaries further and suggest including representatives of the Department of Work and Pensions, who could visit regularly to review case conferences where individuals have complex support needs for their employment.

The occupational health professional skill set involves the following:
- work place risk assessments/advice (for new and expectant mothers in all occupations, lone workers, and those that work in confined spaces);

- sickness absence referrals (short and long term);

- first-line counselling (some of us have first-line CBT training and have developed sessions concerning stress awareness);

- fork lift truck medicals:

- ability to negotiate and navigate through complicated case histories;

- respiratory health surveillance (to include spirometry);

- skin health surveillance (to include latex screening);

- audiometric health surveillance (to include audiometry);

- hand-arm vibration screening;

- night worker health assessments;

- pre-employment health assessments;

- executive medicals;

- first aid at work training/advice; and

- manual handling training/advice.

Let us build a health economy in the community of specialist skills and maybe our innovation will fend off unwanted enforcement as to how we should meet the government targets.

\section{Marie Hickinbotham}

\section{REFERENCES}

1. Department of Health.

healthworkwellbeing.http://www.workingforhealth.go v.uk/Default.aspx (accessed 8 Sep 2009).

2. Professor Field S. RCGP response to NHS Next Stage review (press release).

http://www.rcgp.org.uk/news_and_events/news_roo $\mathrm{m} / \mathrm{rcgp}$ _news_stories/nhs_next_stage_review.aspx (accessed 8 Sep 2009).

DOI: 10.3399/bjgp09X472773 